\title{
Ship Recycling and Its Environmental Impact: A Brief Overview of Bangladesh
}

\author{
${ }^{1}$ Md. Imrul Jobaid, ${ }^{2}$ Md. Moniruzzaman Khan, ${ }^{3}$ A.K.M Kamrul Haque, \\ ${ }^{4}$ Istiaque Ahmed Shawon \\ ${ }^{1}$ Lecturer, Department of Marketing, Faculty of Business Studies, Jagannath University, 9-10, Chittaranjan \\ Avenue, Dhaka-1100, Bangladesh. \\ ${ }^{2}$ BBA, Department of Business Administration, School of Management and Business Administration, Shahjalal \\ University of Science and Technology (SUST), Kumargaon, Sylhet-3114, Bangladesh. \\ ${ }^{3}$ Assistant Professor, Department of Marketing, Faculty of Business Administration, American International \\ University-Bangladesh (AIUB), House \# 58/B, Kemal Ataturk Avenue, Banani, Dhaka-1213, Bangladesh. \\ ${ }^{4}$ BBA, Department of Accounting and Finance, Faculty of Business Administration, American International \\ University-Bangladesh (AIUB), House \# 58/B, Kemal Ataturk Avenue, Banani, Dhaka-1213, Bangladesh.
}

\begin{abstract}
Ship-breaking industry has been playing a great role in the economy via providing raw materials to steel industry, shipbuilding industry and some other industries in Bangladesh. Ship-breaking industries also generate a number of employment opportunities for Bangladesh. Some existing problem like safety of worker, health and working environment issues drawing negative picture of this industry for the country. This paper covers the details of how ship-breaking becoming the successful industry in Bangladesh, existing law for this industry, life of workers involved, and the impact on environment. We have observed issues such as the existing government laws and enforcement, safety of worker, health and working environment situation, remunerations for worker. Aim of this paper is to make out the problematic issues of this industry and then analyze the problems to help to overcome the challenges involved in ship-breaking industry. A brief overview on the socioeconomic profiles and prospect of this industry in global perspective has also been discussed.
\end{abstract}

Keyword: Ship Breaking, Existing laws, safety of workers, Environmental hazards, Child labor.

\section{Introduction}

Ship-recycling is the activity of complete or partially dismantling of a ship at ship breaking yard in order to recover components and materials for reprocessing and re-use. Re-use of scrap iron and steel, which is the most important output of the ship breaking industry, is an environment-friendly activity since it reduces the need for taking out for production per ton of steel industry from pig iron. From energy saving and emission point of view, the production per ton of steel from scrap requires more than 5 times less energy and 7 times less CO2 emission compared to steel production from iron ore (Naser 2008). Thus the ship recycling meets a key sustainability requirement in recycling of resources, if carried out properly.

Ship-recycling is mainly labor rigorous industry and therefore, major ship-recycling countries are mainly developing countries. Until 1970s, ship recycling was a common industrial activity both in the United State of America and in Europe. But boost labor costs and strict environmental regulations caused the scrapping industry to be concentrated at the docksides in Taiwan and South Korea in the 1970s. But those countries lost interest in ship as it was no more cost-effective and they rather focused on using their shipyards for building ship in the 1980s. So, to take full advantage of profits ship owner's found different destinations' in India, China, Pakistan, Bangladesh, Philippines and Vietnam, where healthy and safety standards were negligible and where workers were cheap and desperate for work. Bangladeshi industrialists also took the opportunities of this profitable business which resulted importing more and more ship to Bangladesh. Thus, within a short period, Bangladesh established herself as a leading ship recycling nation in the international market.

Although the age of ship breaking in Bangladesh is more than three decades, but primitive working atmosphere and the lack of compulsory control mechanism generally cause the scrapping yards as a source of environmental and occupational health problems. Moreover, adopted anticipatory actions against the unsafe, primitive conditions of scrapping yards are still below standard.

\section{Objectives of the Study}

1. To find out the process of ship recycling system in Bangladesh.

2. To find out the problems involving in working environment.

3. To measure potentials of this industry in global perspectives. 
History

From 1960 ship breaking industry has started its operation. A Greek ship MD Alpine was remained a long time on the shore Sitakunda and after that Chittagong Steel brought the vessel and scrapped it. During the liberation war a Pakistani ship, Abbas damaged and later Karnafully Metal Works had brought it as a scrap. This was the first commercial ship breaking in Bangladesh. The business flourished during the 1980s. Today it has turn out to be huge and profitable industry of Bangladesh.

\section{Overview of Ship breaking in Bangladesh}

- Ship breaking was strongly considered as a merchandised operation until 1990. On that time it was concentrated for those who are industrialized countries like United Kingdom, Germany, Italy and United States of America. From early 1980s, profitable ship owner use to send their vessels for profit maximization to India, Pakistan, Bangladesh, Vietnams for scraping purpose because here standard of livings are low as well as labors fair and worker are desperate for work. Now a day's more than 100000 worker are working for ship breaking yards all over the world. After completing sailing life ships are sold because of reusing valuable steal.

- In Bangladesh Ship breaking is mainly based on Sitakunda (Bhatiary to Barwalia) which is located at the North of Chittagong, just on the Bay of Bengal. It is very important to the economy of Bangladesh. In our coastal Zone, ship breaking activities are doing both opportunities and threats. Meeting the rising demand for unrefined resources such as steel needs to be fair with the harmful impact this action is having on our coastal atmosphere and on the living conditions of the workers.

- At present, ships are scraping at the shore of north of port city Chittagong which is the second major city of Bangladesh. Labor salaries are the lowest in the world and there is no standard of safety of worker. Beside, environmental policies and laws are not practiced. Clearly there are abundance of opportunities to develop people and the environment when affecting forward with the vessel breaking business.

- Most of the countries of the world, ship breaking is prohibited at beach. People without education and poverty are looking for employment opportunities. They are the main power for this breaking ship industry. In this industry major investment is not essential. At present in Bangladesh, they only need a bulldozer, a big winch and some blowtorches and rest of the operation is done by raw human power. There is no pre-cleaning of the ships are necessary for toward the inside the ship breaking beach in port city.

- At present, India is the business leader of ship yard industry in the world. This country had broken 343 ships which are about 26 per cent of total ships demolished. The position of Bangladesh is third in this industry. In 2013, 210 ships were broken in this industry which is counted as 16 per cent respectively. These three South Asian countries accounted for 71 percent of the worlds scrapped ships. India came in at the top with 2.8 million tones or 31 per cent of total metal recycled globally, while Bangladesh and Pakistan accounted for 2.3 million ( 25 per cent) and 1.4 million ( 15 per cent) respectively, The Express Tribune (2014).

\section{Socio-economic profiles of ship breaking activities:}

Most of the workers are basically come from the northern part of Bangladesh where job opportunities are not available. The ship breaking industry, there is no formal contract between employer and employee. For that reasons workers are totally unable to enforce their rights. Here wages of workers depends on hours based and their level of skills. There are no opportunities for over time and sick leave and the range of wages is mainly from $\$ 1$ to $\$ 1.5$ on daily basis

We have found most of the labor ages between 18 to 22 years old and 1.13\% labor is between $46-60$ years old. We have found that more than $10 \%$ of work forces is under 13 and $46 \%$ of labors are illiterate while $43.03 \%$ were able to attained primary school. There is no opportunity for healthy food, hygienic toilet and medical facilities. We have found only $4.15 \%$ worker said that they got first aid treatment. The factory acts 1965 do not apply for the industry because the government has not recognized it as an industry. Though the staffs have been functioning in the scrap yards for years they are not permitted to form or connect a trade union to good deal and put into effect their rights.

The workers are underprivileged of proper recompense due to the lack of a suitable contract. In arrange to maximize income little attempt is done to minimize the danger of accidents. Accident is common in ship breaking industry, due to mistreatment of processes and not significant if any inflammable chemicals are stocked within or the flaming equipment or situation that ill skilled welding workings never know. As a consequence many explosions have killed a lot of workers in the history of ship breaking industry. It is true that victims of the industry do not report to the police. So that the actual number of victims is unknown. And even right compensation is not given to the victims' family. So environment has negative impact and on the other 
hand individual staffs are not getting good return. This industry pollutes oceanic ecology, sea, water, beaches and bio-diversity.

The industry has been a little moribund due to the international recession and more severe enforcement of countrywide laws and regulations. But the industry is now alternative ways, and the number of ship yards has increased year by year. Ship breaking industry generally generates a lot of opportunities, and it is predictable that some 50000 people are straight employed in the ship breaking business in Bangladesh. In addition, another 100000 are indirectly involved in this industry. Most of the workers are hired by the vessel yards through limited contractors on a ship by ship foundation.

Depending on work type, a worker can earn up to $\$ 3$ dollar. There 300 to 500 employee is being employed on temporary basis. And many of them are employed for downstream activities of reclining activities. We have come to know some of materials are being export and maximum material is using for reused. There is high value of some of material in local market. In particular this raw material is used for road construction, new ship plate and for many purposes.

Up to $60 \%$ steel in local market is basically come from the ship breaking yards in Chittagong. It is estimated that every year new yards are being constructed and more than 100 ship breaking yards along the coastal area of Chittagong. Maximum ship yard owners are local politicians and renowned business men.

A ship is brought around 4 to10 million dollars depending on the condition and size of the ship. Through the middleman ship is being purchased from international sellers. The local ship breaker takes loan from bank with high rate of interest and loan is completely repaid within six months. When ship is completely ripped, all scrap is sold in local as well as in international market.

Working in the yards is really a risky job. Sometimes gases explode kills workers valuable lives. Sometimes workers fall from high sides of the scrap ship or tumbling steel parts on them. Many of them work without goggles. We have come to know that they do not have protecting clothing, shoes. Local organization of Bangladesh have estimated that 1000-2000 workers have died in last 30 years and many of them are suffering from serious diseases. General health survey says that the percentage of disable people is higher than other reasons of Bangladesh.

The workers lack essential equipment. When a new ship has been arrived, there are containers, chambers and tanks, which hold oil, poisonous gases and petroleum. One technique used for examination the level of risk in these parts of the ship is to minor down chickens in a cord to check whether there are unsafe gases. If the chickens stay alive, the earliest workers resolve go into to clean for oil, petroleum and other combustible substances. The flammable substances are often burned off earlier than the shears enter to rip the vessel apart. Gas blast is a common occurrence.

\section{Challenging Scenario of Bangladesh ship-breaking industry:}

Environmental Pollution: ship breaking industry has a great impact on the environment. We found some problems that create environmental pollution. Now we would like to elaborate some findings below.

Pollutants discharged from ship breaking and its impact: We know that ship breaking industry is one of the profitable industries in developing countries like Bangladesh but there are a lot of health and human hazards. Actually it depends on the size and function of ships. Normally scrap ships is between 5000-40000 tones. And from a ship yard owner can get $95 \%$ of steel, 10 to 100 tons of paint, organ tins, arsenic, zinc, cadmium and chromium. Ship not only proves us assets but also huge tons of waste up to various asbestos, thousand litter oils, in addition, hold up to 1,000 cubic meters of lasting oil. The majority of these resources have been defined as unsafe waste. In Bangladesh, ships containing these materials are creature cut up by offer, on open beaches, with no reflection given to safe and environmentally welcoming waste organization practices, Hossain, K.A (2010). From our survey it is really clear that ships are not cleaned perfectly. It is something like eye wash and try to certify ship is fully free from dangerous waste and chemical. This activity is really a threat for both public health and marine environment. It is like a tiny version of a city that discharges each kind of pollutants that a metropolitan area can create like liquid, metal, solid and dangerous solid pollutants.

Persistent Organic Pollutants (POP's): Persistent Organic Pollutants are harmful for the environment, population and wildlife the chemicals are highly toxic and remain a long time to the environment. It also widely distributed biologically and accumulates in the full of fat tissue of living organism. There has been realized by doctors and physicians that these pollutants can cause adverse effects on human body and increased cancer, Ministry of Environment and Forest, GOB (2011).

Asbestos: As a heat insulator asbestos has been used in old ships. Sometime we may think that there is no asbestos in disposal procedure but during the scarping workers are surrounded by asbestos fibers. Exposure of this fiber is very harmful and even it may causes death through cancer. It is true that asbestos fly around the ship breaking beaches and workers take out this chemical with bare hands.

In addition, it has proven to be one of the large amount lethal, as inhaling asbestos fibers can guide to a wide variety of pulmonary troubles such as asthma and asbestosis and can also be the straight cause of mesothelioma. 
Heavy metals: Heavy metals are originated in many parts of ships such as in coatings, paints, coatings, anodes electrical equipment and anodes electrical equipment. These are used apart with no defensive measures in position and reused. The consequences are skin cancer, lung cancer, intestine, liver, Kidney or bladder. It can also reason of spoiling of blood vessels.

Oil pollution: When a ship has been broken in the yard, oil residues are being spoiled and mixed with sea water. This oil is really so much harmful for the environment and marine life. It may cause serious damages in different ways, such as reduction of light intensity beneath the sea surface. Oil on the sea water reduces oxygen and carbon dioxide in the sea interface. It also causes bird reduction in coastal areas. So often spilling may reason wide spread death amongst the fishes, mollusks, mammals, worms, crabs and other water organisms.

Impact of ship breaking on physiochemical properties of seawater: Through we are clear that this scraping activities damage the environment in coastal area mainly of Fauzdarhat to Kumira of Chittagong, Bangladesh. For that reason toxic concentration of ammonia, marine organism is found this area having an increase in $\mathrm{PH}$ level. DO and higher BOD are found with an huge of floatable materials (grease balls and oil films).In ship breaking areas a variety of decline and not reusable materials are discharged and spilled from scrapped vessels and frequently get mixed with the sand. The scraps from ships are staked in a haphazard way in the sea shore. These jointly with widespread human and mechanical activities repeatedly go on as substance of routine work ensuing in the beach soil behind its binding properties and this accelerates the quantity of shore wearing away and enlarge the turbidity of water and sediments in the region.

Workers' Rights Valuation: Occupational health standards is not available and training as well as protection equipment is not provided in ship breaking yard

$\checkmark$ When workers are injured there is no emergency service and access treatment on the job of this industry even ignoring required compensation

$\checkmark \quad$ Wages is less than the standards

$\checkmark$ Child labor is used there

$\checkmark \quad$ No over time

$\checkmark \quad$ There are no specific rules for the job securities

$\checkmark$ They have no rights to form a trade union

In the common of the shipyards, staffs are being underprivileged of their rights. They work under dangerous conditions but have no right of entry to safety equipment, job safety or a living wage.

OHS, accidents and diseases: If we consider last twenty years, more than 400 workers have been killed and 6000 seriously injured this information is according to Bangladeshi Media. From survey we have come to know from a worker Mr Rejathat the explosion of the Iranian tanker TT Dena in May 2000, 50 deaths were occurred. To this charge, thousands belonging to permanent diseases which have occurred and will carry on to occur owing to the toxic equipment that are handled and inhaled lacking any safety measures or defensive gear need to be measured.

If we consider a week, on an average a worker is died and every day, one worker is injured. (End of Life Ships: the Human Cost of Breaking Ships). It is really very easy for any ship owner to replace any workers because if one is lost 10 workers is waiting to replace him on the yard owner. The administration collects the taxes and turns a unsighted eye.

Ship breaking carries danger to life. By any principles, the destruction of ships is unclean and dangerous work. The hazards connected to ship breaking generally fall into two categories: intoxication by hazardous substances and accidents on the plots. Explosions of available gas and smoke in the tanks are the major reason of accidents in the yards. Another main cause of accident is staff falling from the vessels (which is up to $70 \mathrm{~m}$ high) as they are operational with no security harness. Other sources of accidents comprise workers being compressed by falling strengthen beams and tableware and emotional shocks.

Therefore, workers go through from lung problems which cause momentary loss of working ability. The hatches and pockets of ship may hold explosive or flammable gases. The shears, if they appreciate from knowledge, drill little holes in arrange to release gases or smoke. This still however, frequently cause harsh explosions.

There gas cutters and there helpers cut steals without any glasses for their protection. Most of them do not have any uniform and even they don't have any hand gloves and boots. For that reason those people who are unskilled fall in table. They have to carry a large size of steels on their solder and there is no wait limits to carry. Typically, these staff carries weights on top of the limit arranged in the Factories Act and Factories policy.

There we have found that beaches are really strewn with harmful chemicals and toxic substance. Sharp iron sprinters can easily injured any workers. Even workers enter into the ships without protection equipment. So it is clear that occupational health and safety is not priority for the owner of the ship yard and as for the staffs. Their anxious need to find pay to support their families, their livelihoods take priority over their lives. 
Treatment and compensation: When occurrence held, some immediate treatment might be given but there are no facilities or long lasting supports for the injured persons. If we consider compensation, only a minimum compensation is given when there is public pressure unless there is no compensation.

If a staffs is totally unable by any serious accident then he will get 10 thousand to 15 thousand taka ( 1 $\mathrm{USD}=80$ taka and force them to back to their home district. Yes it is true most of the cases the workers will get the transportation cost to go back to their home district.

As well as if a worker is killed by any accident, the contractor just pays the cost of sending the body to the victims' home district and tries to arrange their funeral.

But in case of local workers the procedure is totally different; if they die in the job place their family will receive 50000 taka as compensation. This is mainly happens because yard owners and contactors are unable to avoid the local pressure. According to The staff Compensation Act 1965, only 30,000 taka was projected for a $100 \%$ disable worker and 21,000 taka for departed worker's family. The newly approved Labor Law Act 2006 at the present stipulates that a $100 \%$ disabled employee will be given 100,000 taka.

Child labor: Most of the poor families in Bangladesh depend on child's income for their survival. Four hundred and thirty risky jobs are identified by Bangladesh Shishu Adhikar Forum. And classified those works and declared that 67 of them is so risky work and 11 are dangerous and ship breaking falls in the later.

From YPSA survey we have come to know that $10.94 \%$ of labor force is children (their age varies 718). Most of them are from northern part of this country. Through survey, we are really clear that contractors prefer children than adult because their wages are less.

In the ship yard, children are mainly work as gas cutters assistants and sometimes they move small pieces from one place to another place. They work in two shifts, one starts from sunrise to sunset and another sunset to midnight. On an average, their wage is only 50 to 60 taka per shift. There are no educational or training facilities.

We know that United Nations Convention of the child has been accepted by government in 1990 as well as Bangladesh has a lot of laws related to child protection. In our constitution, article 14 and 15 is about children right. Act no. 28, the state has been specified power to force special order for helping the child's importance. We know that children act 1974 has banned because the use of vulnerable child but it is a matter of great sorrow that we are still doing the same things.

The Law exists: According to Labor Law Act 2006 we have come to know that it has provisions on health safety, leave working condition as well as compensation. But compliance and enforcement is almost nonexistent. There is a huge lacking for political will and government reaction so that owners see no reasons to comply.

Recently Bangladesh Government introduces new policies for the improvement of ecological and occupational health in the industry. But there is a lengthy way to go. As we know our government is not economically strong and laws and enforcement is frequently non existents. Politician and decision maker are so much strong and involved with the industry. For that reasons corruption is being spread everywhere and it is really difficult to enforce the law perfectly.

The ship breaking and ship recycling rules in Bangladesh: 19 ship yards of Sitakunada of Bangladesh visited by several human rights and environmental groups does not give an impression that just only few years ago court of Bangladesh had interviewed to clean the industry following years of movement. There are a number of accidents and death happened in ship breaking industry but only few have been reported. "Last year, 22 workers died while dismantling ships," informs Muhammad Sahin, senior program manager of non-profit Young Power in Social Action (YPSA)." And this year, 7 have died and more than hundred injured.

Rejwan Hasan, director of Bangladesh Environmental Lawyer Association (BELA) says that ship breaking activities is increasing day by day. In 2009, Supreme Court has passed its landmarks judgment and directed the environment ministry for taking necessary steps immediately. At least 60 yards are dismantling the vast hulks for creating the industry second largest in the world. According to an affidavit, submitted by ministry in the court, thirty six of them operating their business without clearness. At present, 150 yards is available and 70 of them are on operation, Watkinson (2012).

Activists disprove the officials' claim. "The management has legalized unlawful ship-breaking yards by generous those permits. These yards fulfill only 10 per cent of the situation outlined in the ecological clearances," Hasan alleges.

The Supreme Court regulation has brought an impermanent halt to illegal actions in ship-breaking yards, says Taslima Rahman of BELA. "But in March 2011 the court unperturbed the order, which has permitted the business to continue as a usual practices," she alleges.

In March 2011, the Supreme Court asked the government for framing the rules and regulation on ship breaking industry within two months. The government has followed the order by month of May of that year but it was behind the seen again. When court asked about delay, Habibur Rahman, deputy secretary of the Ministry of Shipping, told that the SBSR rules are undergoing a process of review by several departments. 


\section{Hope in draft rules}

The draft rules draw round environmental and work-related safety actions that should be undertaken by vessel recyclers, and oblige penalty on defaulters. When accident occurs, ship recyclers have to report to the nearest police station as well as Ship Breaking and Ship Recycling Board (SBSRB). We know that in case of key accidents the ship yard can be suspended for seven years. And the rules are also clear the responsibility regarding the issue of permission of ship breaking.

According to official of DoE, at present ship breaking is treated as like as other industry and ship breaker have to apply for the permission of DoE and ministry of Shipping. "Under the draft rules, a shiprecycler will have to look for no-objection certificates from a crowd of authorities, counting SBSRB, Customs Department and the Department of Explosives. Both DoE and SBSRB will be compulsory to examine the ship for dangerous wastes," says Mohammad Shahjahan, director of DoE.

Long make beaches and perfect slops of Sitakunda helps ship beaching easy. This help to create perfect zone for setting up the yards. "Recently Rampant illegal activities are earning a bad name" said Zafar Alam director of Chittagong DoE. He hopes that if the rules will implement perfectly it will make the industry just hazard free.

\section{Recommendations:}

Ship breaking industry is one of the most potential industries for the economics development of Bangladesh. It is needless to say that it has great impacts on GDP as well. From the above discussions we would like to recommend some essential points which can increase the growth and working environmental safety of this industry in Bangladesh.

1. Existing laws should be strictly enforced by the government.

2. To develop a well-designed working friendly cutting plant, workers safety and environmental issues should be in high concern to make any rules and regulations in this industry.

3. Need to develop a flexible working condition for children as per the ILO convention and the United Nations convention on the right of children.

4. It is very essential to focus on the contribution of the worker those who are involved in this industry and give their continuous effort to national and international economy as well.

5. Government organizations, NGO's, INGO's, civil societies and political leaders should take necessary steps as quickly as possible for ensuring the basic rights of the workers and their family members.

6. Rules and regulations of International Maritime Organization (IMO) and "Hong Kong international convention for safe and environmentally sound recycling of ships" have to be implemented.

\section{Conclusions:}

Ship breaking industry in Bangladesh supports the countries still ship building and other heavy and light engineering industries today. According to FE report, Bangladesh is emerged as the second largest ship breaking nations in the world in 2013.

However problems regarding safety, health and environmental issues, violation of child rights and existing laws and enforcement have created a negative image of this industry, despite the positive contribution to job creations in Bangladesh. The ship breaking industries have great potential in Bangladesh as we are having the longest coastlines in the world. It is still possible to turn ship breaking into a safe and green industry which is considered a hazardous job by taking necessary steps.

To hold Bangladesh's position in world ship breaking, there is no other alternative but to comply with the HKC. The country must upgrade the infrastructure for upstream and downstream waste management, and health issues of the workers (especially for child labor) before trying to get the approval for facilities of the yard. Bangladesh does need to start the process right now; otherwise it might lose the business of ship breaking in the near future.

\section{Reference}

[1]. Naser G, Unsalan D, Tekigul N, Stuer-Lauridsen F. (2008): The ship breaking industry in Turkey: Environmental, safety and health issues, J. Cleaner Production, Vol. 16, No. , pp.350-358.Shipbuilders' association of Japan, (2011): Shipbuilding Statistics.

[2]. Hossain, K.A., Iqbal, K.S. and Zakaria, N.M.G. (2010): Ship recycling prospects in Bangladesh, Proceeding of International Conference on Marine Technology (MATEC2010), 11-12 December, BUET, Dhaka, Bangladesh.

[3]. Hossain, K. A. (2010): Evaluation of potential prospect and challenges of Bangladeshi shipbuilding in the lightof Global contest', M.Sc. Engg. Thesis, submitted to Dept. of Naval Architecture and Marine Engineering, BUET, Dhaka

[4]. M. Shahadat Hossain, Seydur R. Chowdhury, S.M.Abdul Jabbar, S.M. Saifullah and M. Ataur Rahman, (2008): Occupational health hazards of ship scrapping workers at Chittagong Coastal Zone, Bnagladesh, Chiang Mai J. Sci. , Vol. 35, No. 2, pp. 370381

[5]. WB Report (2010): The ship breaking and Recycling industries in Bangladesh and Pakistan, Report no. 58275- SAS, available in http://siteresources.worldbank.org/SOUTHASIAEXT/ Resources/223546-1296680097256/Shipbreaking.pdf

[6]. Ministry of Industry, GOB (2012): The ship Breaking and Ship Recycling Rules 2011, January 11, 2012 
[7]. Ministry of Environment and Forest, GOB (2011): Guidelines on environmental management, waste treatment and workers' occupational health and safety for ship breaking yard in Bangladesh, February 28, 2011

[8]. Kazumichi Shimizu, Yasuo Nakajo, Xinba Yaer, Kooichi Kato, Takahiro Kijima, Isao Teraoka, Hideki Teramachi (2012): Advanced Ship Recycling System- a Pilot Model Project in Muroran Advanced Materials Research, vol. 356-360, pp $1827-1830$

[9]. Watkinson, R. (2012): Waste management in ship recycling yards presented in the seminar on ship-breaking and ship-recycling in Bangladesh and Compliance with International Regulations held in BUET, Dhaka, Bangladesh, 17 January 2012

[10]. Tribune.com.pk, (2014). Despite hard times, Pakistan remains a top ship breaking destination - The Express Tribune. [online] Available at: http://tribune.com.pk/story/657017/despite-hard-times-pakistan-remains-a-top-ship-breaking-destination/ [Accessed 6 Sep. 2014]. 